\title{
Service Performance in Public, Conventional Private and Specialized Private Banks in Bangladesh
}

\author{
Md Abu Saleh ${ }^{1}$ \\ ${ }^{1}$ School of Management, Faculty of Business, Government and Law, University of Canberra, Australia \\ Correspondence: Md Abu Saleh, Associate Professor of Marketing. Tel: 612-6201-2187; Fax: 612-6201-5239. \\ E-mail: abu.saleh@canberra.edu.au
}

Received: November 15, 2017

Accepted: January 30, 2018

Online Published: February 26, 2018

doi:10.5539/ass.v14n3p100

URL: https://doi.org/10.5539/ass.v14n3p100

\begin{abstract}
Banking services play a key role in present competitive environment. Accordingly, service quality, satisfaction and performance have become an area of interest in such research field. An extensive review of the extant literature revealed that very limited explored/uncovered the borrower customers' perception of the conventional public, private and specialised private (Islamic) banking. Therefore, this research strives to integrate a developing country perspective where conventional and non-conventional Islamic banks are operating and providing services to their customers. Data have been collected from 78 borrower customers to examine perceived quality, satisfaction and performances of banks. The study revealed that service performance by the Islamic and conventional private banks were found well-organized and better than public banks. The study finally addressed the limitations and future research directions.
\end{abstract}

Keywords: service performance, private and public bank, Islamic bank, service quality, customer satisfaction

\section{Introduction}

The banking service literature is replete with theoretical and empirical works on a diverse range of issues pertaining to the financial activity of the banks. A systematic search of services marketing literature demonstrates striking imbalance where relatively little attention has been given to the service performance side of the public, conventional private and specialised private banking system. Lassar et al. (2000) argue that as a critical measure of organizational performance, service quality remains at the forefront of both the marketing literature, and the services marketing literature (Jensen \& Markland, 1996; Kant et al., 2017; Sivapalan et al., 2017). Practitioners and academics are keen on accurately measuring service quality in order to better understand its essential antecedents and consequences, and, ultimately, establish methods for improving quality to achieve competitive advantage and build customer loyalty (Palmer \& Cole, 1995; Saleh et al., 2017). Service quality is commonly noted as a critical prerequisite for establishing and sustaining satisfying relationships with valued customers. In this way, the association between service quality and customer satisfaction has emerged as a topic of significant and strategic concern (Taylor \& Baker, 1994). In general, research in this area suggests that service quality is an important indicator of customer satisfaction and performance (Spreng \& Mackoy, 1996).

In sync with other business organisation, however, banking services play a key role in present competitive edge. In whatever way, either private/public or Islamic/non-Islamic banking service, customer satisfaction is a significant aspect to gain market share and retain in the market. Accordingly, service quality has become an area of interest in such research field (Lee et al., 2000). It is important from many perspectives such as: first from the competitive context, bank as a service organisation can enhance its capability to retain with the existing customer and to attract new valuable customer through service performance. Second, from the profit orientation, bank can maximise its profit toward betterment of its long-term prospects. Third, from the self-existence context, bank services can ensure their own long-term benefits. However, in the context of Islamic bank, service provider has sprit of religiosity.

In addition, service marketing being the dominant part in customer satisfaction and performance outcome, there are opportunities to investigate the spectrum of comparative services in a specific context. Although the underlying notions of the Islamic banking system are not similar to the non-Islamic banking system, Islamic banks face strong competition from both Islamic and conventional public and private banks (Naser \& Moutinho, 1997). Specifically, in the context of Bangladesh, the review of the literature shows that till date, so far there has very limited effort been made to investigate the service performance and customer satisfaction level in Islamic 
bank in comparison to other conventional banks. Hence, it is of paramount importance to assess the marketing effectiveness as well as competitive services of the Islamic banks with other private and public banks. Accordingly, the central research question to be addressed in this proposed study is:

What are the levels of customer satisfaction in Islamic Bank Bangladesh Ltd. (IBBL) and other conventional (Public and Private) banks' services in Bangladesh and how do they impact on performance of those banks?

To answer the above research questions, the aims of this study are:

i) To evaluate and measure the service quality and customer satisfaction; and

ii) To find out the level of service competition between the IBBL and conventional banks (Public and Private)

\section{Justification of the Study}

Currently the banking industry is fronting stern competitive pressures and faces an increasingly sensitive clientele. This dynamic frontier allows a bank to differentiate itself tactically from its competitors by enlightening service quality, enhancing accessibility and responding to customer demands and improving performance (Yavas \& Yasin, 2001). Furthermore, the gaps between the back and front stage service operations are common sources of complaints and dissatisfaction within and among bank customers (Coskun \& Frohlich, 1992; Shemwell \& Yavas, 1999). These, in turn, determine the overall banking performance or the strategic effectiveness of a bank as an effective operational system. So, it is justified to study banks' performance in terms of its providing services.

Furthermore, both that private and public-sector banks have been playing a key role in Bangladesh economy. More specifically, Islamic banking services have been playing a vital role in the economy of Bangladesh due to its favourable socio-economic condition. Being the second largest Muslim country in the world, Islamic banking system is very much popular due to the moral support of the people of Bangladesh. Although the expectations from public and conventional private banks are similar, the religiosity of the people of the country intensify the expectation of a cordial, sincere and heart-warming services from Islamic banks. Whether that expectation has been materialised is a question yet to be answered. The present study attempts to find out the actual situation of the institution introspect of their services.

\section{Contributions of the Study}

The study makes contributions in many ways. First, from the theoretical perspective, the current study aims to use current service marketing concept in the banking sector. As discussed earlier, there are so many directions of investigation in service sector. However, this study incorporates service marketing phenomena in banks specifically traditional conventional banking services and non-conventional banking services, for example Islamic banking services. Hence, this research validates the extant findings in different context by extending their tenets into new additional area. Second, the review appears to indicate discrepancies, and lack of consensus among researchers on the possible area of research. Although many inquiries have been made in different context, most of those appear ad hoc, without validating the results. Therefore, the study contributes to the literature by validating some of those aspects in a new context. Third, this study contributes to the literature by examining both private and public banking services toward comparing customer satisfaction in rendered services. Fourth, the study attempts to fill the contextual gap in the extant literature. As discussed in the review section, the theoretical development and empirical testing of the theories in this field has been based only on the developed country context. Nevertheless, understanding the services of banks from less developed and developing countries is equally important for clear comprehension of the phenomena for academics, managers and policy makers. Therefore, the study contributes to the literature by incorporating developing country phenomena toward empirical expansion of the findings.

\section{Literature Review}

An extensive search of literature shows 51 studies focused on banking services in different context. Among these, five studies emphasized on services from strategic point of view, eight studies focused on organization perspective, nine studies investigated electronic banking services, three studies examined competitive situation in service sector, four studies highlighted on Islamic banking practices in developed countries, 19 studies emphasized and investigated quality services in banks, and only three studies relate Islamic banking in Bangladesh. In this study, literature related to competitive scenario, Islamic banking, service quality and country context have been considered toward narrowing the research question. All those sequential but supportive streams provide impetus to specify the research gap.

Naser and Moutinho (1997) clearly focused on understanding of Islamic and non-Islamic banking. The purpose 
of Islamic banks is to invest funds in accordance with the Islamic Sharia'h towards the advancement of the societies (Islamic and non-Islamic) in which they are operating. According to Siddiqui (1985), compared with the non-Islamic banking system, Islamic banking upshots in a more just and equitable distribution of resources. In a non-Islamic bank, the involvement of borrower investor (bank) is not profit sharing. Additionally, it has been repeatedly argued that the involvement of the Islamic bank in profit sharing ties between the bank and its customers. Whatsoever the theoretical arguments for the Islamic banking system may be, Islamic banks find themselves competing with well-established public and private conventional banks and with each other, and as competition grows up, a firm's life span becomes challenging. Thus, the Islamic bank should be able to mobilize its resources to achieve the relative competitive advantage. This can be dealt with through the formation of faithful business and trained personnel where quality services to the customer can play a most vital role.

Coskun and Frohlich (1992) emphasised that as competition increases and profitability affects, banks must develop a competitive advantage over other financial institutions. Henceforth, customer service plays a pivotal role in the development of high quality service and helps to face severe completion. In the same way, Michel (2004) argues that it is broadly accepted that superior bank service performance leads to higher client satisfaction. Conversely, service failures have a negative impact on satisfaction. Therefore, to face competition in banking sector, efforts should be made to increase customer satisfaction through better services in all respects.

Haron (1994) has analysed "Bank Patronage Factors of Muslim and Non-Muslim Customers". In his study, Haron (1994) outlined that banks are not only competing with themselves, but also with some other financial institutions within the same industry. In a plural developing society such as in Malaysia, the competition is becoming sterner with the existence of the Islamic bank that was established specifically to tailor the needs of the Muslim consumers in the country. To attract more clients/customers, both conventional and Islamic banks should have information on elements/factors used by customers in selecting their banks.

Furthermore, service quality is a key considerable factor in banking services in current era across the world. Thus, banks are trying to enhance their existing services with quality toward improving customer satisfaction. Mahadevan and Balasubramanian (2001) mentioned that service quality is an subtle and impede construct that is somewhat difficult to define and measure. In their article Yavas and Yasin (2001) analysed quality service and customer satisfaction. The research presents a framework, which has not been empirically tested. Teas (1993) asserts that service quality has received considerable attention in the marketing literature where service quality gap concept has received the most attention is the expected service and perceived service. This approach could be an instrumental to verify banking services in a developing country context. Although Parasuraman et al. (1985) defines quality as conformance requirement, which is very difficult to measure, because different bank customers have diverse requirements. Further, Parasuraman et al. (1991) investigated service quality scale and found dimensions of service quality measure such as tangibility, reliability, responsiveness, assurance, and empathy. However, Carman (1990) found five more additional service quality dimensions. These dimensions could be used in measuring banking services in any other context.

Similarly, Lassar et al. (2000) assert that research in the area of service marketing in bank has begun to address whether or not service quality differentially affects satisfaction. As a critical measure of bank performance, service quality remains at the forefront of both the services marketing literature generally, and the banking services literature specifically (Jensen \& Markland, 1996). Practicing managers and academics are keen on precisely measuring service quality to better comprehend its essential antecedents and consequences, and, ultimately, establish methods for improving quality to achieve competitive advantage and build customer loyalty (Jaiswal et al., 2017; Kant et al., 2017; Palmer \& Cole, 1995). Service quality is generally noted as a critical condition for establishing and sustaining satisfying relationships with valued bank customers. In this way, the association between service quality and customer satisfaction has emerged as a topic of significant concern (Heinberg et al., 2017; Taylor and Baker, 1994). The study examines the effects of service quality on customer satisfaction from two perspectives. Overall, findings of their study are significance to service managers as they endeavour to identify effective approaches for improving quality. It is also argued that not only has quality in professional services in bank emerged recently as an important area of research, but customer satisfaction is known to be a critical element of success for banking services. As used in other studies (Blanchard \& Galloway, 1994; Jabnoun \& Al-Tamimi, 2003; Parasuraman et al., 1991), five dimensions of service quality measures found significant impact of all those measures. Accordingly, Jabnoun and Al-Tamimi (2003) argue that banks service quality is commonly noted as a prerequisite for satisfying valued customers to uphold their market share.

In a different context, Allred and Addams (2000) have investigated customers' perception on service quality at bank and credit unions and to determine (bank and credit union) their service quality performance. By contrast, the findings of their study indicate that neither banks nor credit unions do a good job of satisfying customer 
needs or retaining customers. This finding is still ad-hoc and could be validated in terms of service quality and customer satisfaction in any developing country context.

In addition, a comprehensive study by Kwan and Hee (1994) asserted that high service quality result in higher customer satisfaction. The finding of their study has emphasised on service quality in Singapore retail banking. It is found that overall; performance as perceived by customers was below their expectorations scores all service quality dimensions. It is also found that customer satisfaction in terms of service quality of bank is below average. However, it still falls short of customer expectations. This is an important impetus to validate this finding in Bangladesh context; especially comparative situation such as Islamic and conventional banking service quality could be examined.

A comparative study between publicly quoted bank and a government bank in Singapore has investigated bank service quality (Gerrard and Cunningham, 2001). The results showed that consumer inclinations about an outstanding bank's service quality were not significantly different as between the publicly quoted bank and government bank. The perceptions that consumers had about the service quality of the bank they supported, though, showed some considerable differences. The publicly quoted bank was perceived as having a better services portfolio, specifically regarding creating customers awareness of its services and offering a variety of services through its ATMs. This is an important finding which can be validated in a developing country context such as comparing services between private and public bank sector in Bangladesh.

Duncan and Elliott (2002) investigated customer service quality and financial performance among Australian retail financial institutions. The results of their study show that all financial performance measures are positively associated with customer service quality scores. This means that customer satisfaction through services increase financial performances in the banks. This finding needs to validate in any other context.

Lee et al. (2000) deals with three different issues in the area of perceived service quality. First, it compares the gap model with the performance model. Second, it examines the direction of causation between service quality and satisfaction. Finally, it investigates whether the influences of some dimensions of service quality differ across service business types. The result shows that perceived service quality is an antecedent of satisfaction, rather than the other way around. This result infers that service managers should place importance on performance perceived by customers rather than the differences between perceived performance and preceding expectation. This is similar to the research issue posed in this study.

As compare to a developing country India, banking services as well as perspective has investigated by Indian Institute of management, Ahmedabad (IIMA, 2002). The study states the public sector commercial banks contributed substantially to the social transformation processes but at the same time the process of qualitative transformation related to the service profile enthused in the reverse gear. The study found that most of the consumers prefer nationalized banks to open savings bank $\mathrm{A} / \mathrm{C}$ followed with private and Co-operative Banks. Majority of them agreed with services like availability of staff, services as being provided to them and response to their quires. The study further tried to assess performance of various banks in terms of time taken by them in providing services. In brief, public banks were found efficient in providing services like cash deposit, issuance of demand draft, issuance of cheque book, and making entries in the passbook. But some of the customers felt long time taken by banks in completing transaction, opening a deposit account, cash withdrawal, and collection of outstation cheques. Majority of them were found satisfied in terms of time taken by banks in providing certain services viz., cash withdrawal, issuance of demand draft, issuance of cheque book, renewal of fixed deposit receipt, and making entries in the passbook. These findings are tentative and not validated in similar context. Thus, this is an impetus to investigate the spectrum of service marketing of banks in Bangladesh to verify the above findings in a different context.

In respect of Islamic banking services in Bangladesh there is dearth of literature even after twenty years of its existence. Huq (1996) studied "Islamic Banking in Bangladesh with a Brief Overview of Operational Problem." The study examined various aspects such as sources of funds, uses of funds, Shriah principles in investments, collateral policy etc. and some operational problems of the Islamic Banks. Loqman and Muhiuddin (1998) gave brief account of financial performance dependability on productivity, which is dependent on manpower productivity being bank service oriented sector. Rahman (2001) has categorically mentioned about the dearth of adequately trained manpower in the newly emerging Islamic Banking sector to dispense with services effectively. A recent study by Saleh et al., (2017) examined the quality and image of public and Islamic banking services. This study also ignored the measure of various service performance outcomes.

The above review consolidates all directions of service marketing in banks in general and specific to the relevant context toward narrowing the research question posed in this study. Customer satisfaction and service marketing 
have been received a substantial attention in investigating the phenomena in developed country context. Additionally, service tools and techniques also have been playing a significant role in the same direction of academic research. Quality, however, has taken most important place in the same context of research. By contrast, the above review indicates that so far there is little attempt has been made to investigate the phenomena whether any attention is going on with customer care in Bangladesh. Therefore, an endeavour has taken to investigate a comparative situation of services-customer satisfaction level between a specialized bank such as Islamic bank and other public and private conventional bank. The above discussion clearly indicates that customer satisfaction has a direct relationship with performance of bank and quality of bank services also has an influence on bank performance. In addition, quality of bank services may have some impact on customer satisfaction.

\section{Methodology}

Researchers (for example, Strauss, \& Corbin, 1990) emphasised and indicate the justification of combining both qualitative and quantitative within a research approach. This is important not only for developing or extending theoretical arguments and testing their applications, but also to achieve higher degree of credibility between methods through enhancing the quantitative output with rich interview data. As Beedles (2002) argues, these two methodologies are synonymous with the rational positivist and idealist paradigms successively and represent both extremes on a cohesive paradigmatic approach (Deshpande, 1983). As such, an endeavour has been made to incorporate both qualitative and quantitative data to discuss the findings of this study. The remainder of the following sections discusses the population of the study, research instrument, data collection, and data analysis.

\subsection{Population and Sample of the Study}

While the activity of banking services plays a significant role in world business, it is also dominating and controlling all other financial institutions across the globe. In common with most of the other developing countries of the world, Bangladeshi banks also played a significant role in operating international and local business. In Bangladesh, out of more than fifty financial institutions only four are Islamic banks and out of all conventional financial institutions only three banks are public and rest of them are private and foreign. Due to time and resource constraints data have been collected from selected branches of all three categories of banks to analyse the performance of their existing services. To attain a certain amount of variance in data, this study only focused on the private and public-sector banking in Bangladesh. The practical reason for excluding central banking services is to ignore inter banking services which is not directly relevant to general services and satisfaction in banking sector. The rationales for selecting single country Bangladesh as a context are: to reduce the variations of multi country banking services, the researcher is a native of Bangladesh, and the study provided more interesting insight into banking sector in Bangladesh. Specifically, it has provided a comparative picture of Islamic and other conventional banking service scenarios of Bangladesh.

\subsection{Research Instruments}

The extant service marketing of bank studies measured customers' subjective assessment of services, quality of services and performance of bank. Consequently, the present study measures Bangladeshi banks' services and their performances. One set of semi structured survey questionnaire was developed to collect necessary information from customer/borrower. The information includes their perceptions of services, quality of bank services, and their satisfaction. Having some subjective rating scale, a semi-structured questionnaire has been designed incorporating all dimensions of services to facilitate self-administration of the questionnaire. An original English version of the questionnaire was reviewed by a panel before pre-testing. According to the reviewers, the questionnaire was revised and modified. The modified version was pre-tested for its clarity and reliability on a small sample of Rajshahi City, Bangladesh. Based on the pre-test feedback, the flow and wording of the questionnaire was slightly modified. To facilitate quick easy response, the questionnaire was translated into Bangla. Direct translation method was used to translate the questionnaire into Bangla (Brislin, 1970; Malhotra et al., 1996). To get more clarity, the Bangla version of this questionnaire was pre-tested again.

\subsection{Data Collection}

For collecting primary data, questionnaire was developed for customer borrowers of Islamic Bank Bangaldesh Ltd. and conventional public (Agrani bank) and private (National Bank Ltd.) banks. The study has accommodated primary as well as secondary data. The study has covered four metropolitan cities of the country viz; Dhaka, Khulna, Chittagong and Rajshahi these are the nerve centres of business and trade \& commerce in the country. To evaluate the performances of services of the banks, data published in the Annual Reports have been used as a secondary source. 
The commonly used personal interview technique in the developing country has been used for its credibility to collect data parsimoniously at a short period of time from the scattered varied sources. Thus, at the very beginning of the survey, different bank branches have been contacted and respondent has been drawn randomly from borrower customers list of the selected bank branches. The sampling procedure was purposive because the number of borrower customer of any bank is lower than regular bank customer. Primary data collections include questionnaire and personal interview. There were open-ended and closed-ended questions and interviews were semi structured type. As shown in Table 1, mostly equal representative of the borrower customers was drawn basically from two groups of banks such as Islamic bank and conventional banks. A total of 78 responses were recorded from both groups where Islamic bank customers were 39 and Public (22) and Private conventional (17) bank customers were 39 .

Table 1. Borrowers' Demographic Profile of Islamic, Public and conventional private banks

\begin{tabular}{|c|c|c|c|c|}
\hline Factors & Islamic $^{*}$ & Public $^{* *}$ & Conventional Private $^{* * *}$ & Total \\
\hline \multicolumn{5}{|l|}{ Age: } \\
\hline $15-24$ & 3 & 1 & 2 & 6 \\
\hline $25-34$ & 19 & 7 & 2 & 28 \\
\hline $35-44$ & 12 & 10 & 10 & 32 \\
\hline 45-Above & 5 & 4 & 3 & 12 \\
\hline \multicolumn{5}{|l|}{ Sex: } \\
\hline Male & 35 & 20 & 15 & 70 \\
\hline Female & 4 & 2 & 2 & 8 \\
\hline \multicolumn{5}{|l|}{ Education: } \\
\hline Masters & 12 & 8 & 6 & 26 \\
\hline Hons/Pass Graduate & 9 & 6 & 7 & 22 \\
\hline H.S.C & 11 & 6 & 3 & 20 \\
\hline S.S.C & 7 & 2 & 1 & 10 \\
\hline Total responses & 39 & 22 & 17 & 78 \\
\hline
\end{tabular}

Notes: ${ }^{*}$ Islamic Bank Bangladesh Ltd., ${ }^{* *}$ Agroni Bank, and ${ }^{* * *}$ National Bank Private Ltd.

The success of banks in articulating effective marketing plans largely depends on customers' information profile. This includes customer age, education occupation, and other socio-demographic information. The availability of such a comprehensive profile provides the strength of data. Accordingly, the above table focused on demographic factors to inform whether any impact of these factors on selecting banks and perception on the customer services. The table shows that the representations are sequential, equal and temporal.

\section{Analyses and Findings of the Study}

The comparative analysis has been conducted to gain feedback regarding the understanding of the scoring process and clarity of the factor statements. SPSS software has used to record and analyse the raw data. Cross response analyses have already been conducted. Mean and \% of responses in each dimension of response also have analysed. After wards the results sample survey have summarized and reported using appropriate tables. The following tables and sections of this study have discussed the findings of analyses and implications.

Table 2. Significance of selecting Islamic Bank by borrower customers

\begin{tabular}{lccc}
\hline \multicolumn{1}{c}{ Factors } & Total Score & Mean & Mean Rank \\
\hline Personal Relationship with Employees & 150 & 4.05 & 1 \\
Religious aspects & 133 & 3.91 & 2 \\
Location of the Bank & 85 & 2.66 & 3 \\
Quality Service Management & 72 & 2.25 & 5 \\
Reputation of the Bank & 61 & 1.85 & 6 \\
Financial Condition & 45 & 2.64 & 4 \\
\hline
\end{tabular}


Table 3. Satisfaction rating of various Islamic Bank services

\begin{tabular}{lccc}
\hline \multicolumn{1}{c}{ Factors } & Total Score & Mean & Mean Rank \\
\hline Simplified procedure of investment & 86 & 3.91 & 1 \\
Employee Behaviour & 90 & 3.46 & 2 \\
Easy Investment Negotiation Process & 91 & 3.25 & 3 \\
Quickness of Cash Deposit & 99 & 2.91 & 4 \\
Quickness of Collection of Cheque & 89 & 2.70 & 5 \\
Quickness of Cheque Encashment & 69 & 2.37 & 6 \\
\hline
\end{tabular}

Table 4. Rating of Islamic Banks' service quality by borrower customers

\begin{tabular}{lccc}
\hline \multicolumn{1}{c}{ Factors } & Total Score & Mean & Mean Rank \\
\hline Management Efficiency & 164 & 4.43 & 1 \\
Response & 112 & 3.29 & 2 \\
Performance of banking services & 93 & 2.66 & 3 \\
Reputation & 78 & 2.36 & 4 \\
Employee commitment & 61 & 2.10 & 5 \\
Reliability & 54 & 2.84 & 6 \\
\hline
\end{tabular}

Table 5. Rating of service performance of Islamic Banks

\begin{tabular}{lccc}
\hline \multicolumn{1}{c}{ Factors } & Total Score & Mean & Mean Rank \\
\hline Training and Skill & 171 & 4.62 & 1 \\
Manpower and Equipment & 91 & 2.94 & 2 \\
Speed of Transaction & 84 & 2.8 & 3 \\
Internet Services & 93 & 2.74 & 4 \\
Working Environment & 52 & 2.71 & 5 \\
Automation Services & 72 & 2.32 & 6 \\
\hline
\end{tabular}

The above tables (tables 2 to 5) reveal the finding of Islamic bank borrower customer ratings of selecting Islamic banks, customer satisfaction ratings, quality ratings and performance ratings. As perceived by the respondents, the most significant rating is service performance of Islamic banks in terms of training and skill of employees.

Table 6. Significance of selecting Public Bank by borrower customers

\begin{tabular}{lccc}
\hline \multicolumn{1}{c}{ Factors } & Total Score & Mean & Mean Rank \\
\hline Personal Relationship with Employee & 97 & 4.41 & 1 \\
Interest/profit & 56 & 3.29 & 2 \\
Quality Bank Management & 64 & 3.05 & 3 \\
Location of the Bank & 70 & 3.04 & 4 \\
Financial Condition & 28 & 2.55 & 5 \\
Reputation of the Bank & 30 & 1.67 & 6 \\
\hline
\end{tabular}

Table 7. Satisfaction rating of various public bank services

\begin{tabular}{lccc}
\hline \multicolumn{1}{c}{ Factors } & Total Score & Mean & Mean Rank \\
\hline Quickness of Cheque Encashment & 72 & 3.27 & 1 \\
Quickness of Collection of Cheque & 70 & 3.18 & 2 \\
Investment Negotiation Process & 59 & 2.95 & 3 \\
Employee Behaviour & 31 & 2.58 & 4 \\
Simplified Procedure of Investment & 36 & 2.57 & 5 \\
Quickness of Cash Deposit & 56 & 2.55 & 6 \\
\hline
\end{tabular}


Table 8 . Rating of public banks' service quality by borrower customers

\begin{tabular}{lccc}
\hline \multicolumn{1}{c}{ Factors } & Total Score & Mean & Mean Rank \\
\hline Management Efficiency & 104 & 4.73 & 1 \\
Response & 53 & 2.79 & 3 \\
Performance of banking services & 65 & 3.25 & 2 \\
Reputation & 38 & 1.90 & 6 \\
Employee commitment & 52 & 2.74 & 4 \\
Reliability & 45 & 2.5 & 5 \\
\hline
\end{tabular}

Table 9. Rating of service performance of public Banks

\begin{tabular}{lccc}
\hline \multicolumn{1}{c}{ Factors } & Total Score & Mean & Mean Rank \\
\hline Training and Skill & 89 & 4.05 & 1 \\
Manpower and Equipment & 41 & 2.56 & 4 \\
Speed of Transaction & 34 & 1.79 & 6 \\
Internet Services & 48 & 2.82 & 3 \\
Working Environment & 52 & 2.89 & 2 \\
Automation Services & 44 & 2.44 & 5 \\
\hline
\end{tabular}

The above tables (tables 6 to 9) reveal the finding of public bank borrower customer ratings of selecting public banks, customer satisfaction ratings, quality ratings and performance ratings. As perceived by the respondents, the most significant rating is management efficiency of public banks.

Table 10. Significance of selecting conventional private bank by borrower customers

\begin{tabular}{lccc}
\hline \multicolumn{1}{c}{ Factors } & Total Score & Mean & Mean Rank \\
\hline Personal Relationship with Employee & 63 & 3.71 & 1 \\
Interest/profit & 12 & 2.00 & 6 \\
Quality Bank Management & 58 & 3.41 & 2 \\
Location of the Bank & 52 & 3.25 & 3 \\
Financial Condition & 23 & 2.3 & 4 \\
Reputation of the Bank & 35 & 2.5 & 5 \\
\hline
\end{tabular}

Table 11. Satisfaction rating of various conventional private bank services

\begin{tabular}{lccc}
\hline \multicolumn{1}{c}{ Factors } & Total Score & Mean & Mean Rank \\
\hline Simplified procedure of investment & 48 & 3.69 & 1 \\
Quickness of Cheque Encashment & 58 & 3.63 & 2 \\
Quickness of Cash Deposit & 42 & 2.80 & 3 \\
Quickness of Collection of Cheque & 31 & 2.07 & 6 \\
Investment Negotiation Process & 26 & 2.60 & 4 \\
Employee Behaviour & 36 & 2.4 & 5 \\
\hline
\end{tabular}


Table 12. Rating of conventional private banks' service quality by borrower customers

\begin{tabular}{lccc}
\hline \multicolumn{1}{c}{ Factors } & Total Score & Mean & Mean Rank \\
\hline Management Efficiency & 79 & 4.65 & 1 \\
Employee commitment & 55 & 3.24 & 2 \\
Response & 26 & 2.17 & 5 \\
Performance of banking services & 48 & 3.00 & 3 \\
Reputation & 35 & 2.18 & 4 \\
Reliability & 12 & 1.71 & 6 \\
\hline
\end{tabular}

Table 13. Rating of service performance of conventional private banks

\begin{tabular}{lccc}
\hline \multicolumn{1}{c}{ Factors } & Total Score & Mean & Mean Rank \\
\hline Training and Skill & 76 & 4.47 & 1 \\
Manpower and Equipment & 50 & 3.57 & 2 \\
Speed of Transaction & 39 & 2.43 & 5 \\
Internet Services & 44 & 2.75 & 3 \\
Working Environment & 30 & 2.73 & 4 \\
Automation Services & 15 & 1.5 & 6 \\
\hline
\end{tabular}

The above tables (tables 10 to 13) reveal the finding of conventional private bank borrower customer ratings of selecting private banks, customer satisfaction ratings, quality ratings and performance ratings. The perception of the respondents is consistent with public banks where the most significant rating is management efficiency of private banks.

Table 14. Overall analysis of performance of bank staff in time taken for completion of transaction

\begin{tabular}{clccc}
\hline SN & \multicolumn{1}{c}{ Assumptions } & $\mathrm{IBBL}^{*}$ & $\mathrm{AB}^{* * *}$ & $\mathrm{NBL}^{* *}$ \\
\hline 1 & Time taken for completing transaction & $33 \mathrm{~min}$ & $42 \mathrm{~min}$ & $24 \mathrm{~min}$ \\
2 & Time taken for cash withdrawal & $25 \mathrm{~min}$ & $32 \mathrm{~min}$ & $19 \mathrm{~min}$ \\
3 & Time taken for cash deposit & $15 \mathrm{~min}$ & $22 \mathrm{~min}$ & $12 \mathrm{~min}$ \\
4 & Time taken for renewal of fixed deposit & $44 \mathrm{~min}$ & $55 \mathrm{~min}$ & $39 \mathrm{~min}$ \\
5 & Time taken for opening a deposit account & $50 \mathrm{~min}$ & $60 \mathrm{~min}$ & $40 \mathrm{~min}$ \\
6 & Time taken for collection of cheques (local) & 2 days & 2 days & 2 days \\
7 & Time taken for issuance of demand draft & $55 \mathrm{~min}$ & $66 \mathrm{~min}$ & $45 \mathrm{~min}$ \\
8 & Time taken for issuance of telephone transfer & $23 \mathrm{~min}$ & $34 \mathrm{~min}$ & $25 \mathrm{~min}$ \\
9 & Time taken for issuance of chequebook & $20 \mathrm{~min}$ & $35 \mathrm{~min}$ & $18 \mathrm{~min}$ \\
10 & Time taken for issuance of withdrawal slip & $5 \mathrm{~min}$ & $10 \mathrm{~min}$ & $5 \mathrm{~min}$ \\
11 & Time taken for making entries in the passbook & $25 \mathrm{~min}$ & $28 \mathrm{~min}$ & $22 \mathrm{~min}$ \\
12 & Time taken for sanctioning new loan & $1 \mathrm{month}$ & 1 month & 2 months \\
\hline
\end{tabular}

Notes: ${ }^{*}$ Islamic Bank Bangladesh Ltd., ${ }^{* *}$ Agroni Bank, and ${ }^{* * *}$ National Bank Private Ltd.

As shown in Table 14, the study made an endeavour to assess performance of numerous banks in terms of time taken by them in providing services. In short-term, public banks were found effective in providing various services like cash deposit, issuance of cheque book, issuance of demand draft, and making entries in the registrar. But some of the consumers perceived long time taken by banks in completing transaction, cash withdrawal, opening a deposit account, and collection of outstanding cheque. 60 per cent of the customers were dissatisfied and perceived that the sanctioning of loan by the public banks took a longer time in finalizing the transaction. 
The study revealed that time taken by the Islamic and conventional private banks were found well-organized in providing services like issuance of demand draft, issuance of money transfer, opening a deposit account, and issuance of telegraphic transfer except cash deposit, cash withdrawals. But some of them perceived long time taken by these banks in completing one transaction, making entries in the registrar, renewal of fixed deposit receipt, and approving loan. The qualitative analysis, however, for this study has explored the patterns of services and customer satisfaction of Islamic and conventional banks in Bangladesh. Further, this has enabled the mechanisms and dynamics of formulated research model in this respect toward comparing proposed links by seeking more specific information in a qualitative approach. Such attempt revealed that most of the quantitative findings are similar.

\section{Conclusions and Limitations of the Study}

The present study strives to explore the service marketing in Islamic banks and its challenges with other private and public banks using data from a developing country, Bangladesh. The study contributes to the extant services marketing theories in traditional private and public vs non-traditional Islamic banking settings. The findings contribute to our understanding that the services of Islamic banking are highly driven by religiosity as compared to other two banks in terms of sanctioning loan and bribery practice. However, various inherent constraints and limitations may affect the ability to generalise the results of this study. This section discusses limitations only in respect of methodology to be followed. First, data collected have only been from the three banks may not represent the other banks' situation in Bangladesh. This has explored only a representative of borrower customers' perceptions of the banker-customer relationship which may limit the holistic view of the study. Second, the study deals with only one category of respondents, which may not represent the entire population of customer-banker relationship to identify possible differences among others. Third, the findings rely on cross-sectional data, rather than longitudinal. This may affect the generalisability of the findings. Any future research agenda might be interesting to fill these gaps.

\section{References}

Allred, A. T., \& Addams, H. L. (2000). Service quality at banks and credit unions: What do their customers say? International Journal of Bank Marketing, 10(1), 52-60. https://doi.org/10.1108/09604520010307049

Beedles, M. T. F. (2002). The uncertain role of alliances in the strategic armory of the dominant firms in the global pharmaceutical industry (Unpublished Doctoral Thesis). Queensland University of Technology.

Blanchard, R. F., \& Galloway, R. L. (1994). Quality in retail banking, International Journal of Service Industry Management, 5(4), 5-23. https://doi.org/10.1108/09564239410068670

Brislin, R. (1970). Back translation for cross-cultural research. Journal of Applied Psychology, l(1), 185-216. https://doi.org/10.1177/135910457000100301

Carman, J. M. (1990). Consumer perceptions of service quality: An assessment of the Seroquel dimensions. Journal of Retailing, 66(1), 33-55. Retrieved from https://search.proquest.com/openview/9b58a6fed9a0397 0daaa0c1557ae 7bb2/1?pq-origsite $=$ gscholar \&cbl $=41988$

Coskun, A., \& Frohlich, C. L. (1992). Service: The competitive edge in banking. Journal of Services Marketing, 6(1), 15-22. https://doi.org/10.1108/08876049210035700

Deshpande, R. (1983). Paradigms lost: On theory and method in research in marketing. Journal of Marketing, 47, 101-110. https://doi.org/10.2307/1251403

Duncan, E., \& Elliott, G. (2002). Customer service quality and financial performance among Australian retail financial institutions. Journal of Financial Services Marketing, 7(1), 25-41. https://doi.org/10.1057/palgrave.fsm.4770070

Gerrard, P., \& Cunningham, B. (2001). Bank service quality: A comparison between a publicly quoted bank and government bank in Singapore. Journal of Financial Services Marketing, 6(1), 50-66. https://doi.org/10.1057/palgrave.fsm.4770040

Haron, S., Ahmed, N., \& Planisek. (1994). Bank patronage factors of Muslim and non-Muslim customers. International Journal of Bank Marketing, 12(1), 32-40. https://doi.org/10.1108/02652329410049599

Heinberg, M., Ozkaya, H. E., \& Taube, M. (2017). Do corporate image and reputation drive brand equity in India and China? Similarities and Differences. Journal of Business Research. https://doi.org/10.1016/j.jbusres.2017.09.018

Huq, M. A. (1996). Islamic banking in Bangladesh with a brief overview of operational problems. Bank 
Parikrama, Quarterly Journal of Bangladesh Institute of Bank Management.

IIMA. (2002). Banking services in India: A comparative study. Indian Institute of Management, Ahmedabad.

Jabnoun, N., \& Al-Tamimi, H. A. H. (2003). Measuring perceived service quality at UAE commercial bank. International Journal of Quality \& Reliability Management, 20(4), 458-472. https://doi.org/10.1108/02656710310468614

Jaiswal, A. K., \& Lemmink, J. G. (2017). Investigating a comparative evaluation approach in explaining loyalty. Marketing Intelligence \& Planning, 35(7), 937-954. https://doi.org/10.1108/MIP-03-2017-0061

Jensen, J. B., \& Markland, R. E. (1996). Improving the application of quality conformance tools in service firms. Journal of Services Marketing, 10(1) 35-55. https://doi.org/10.1108/08876049610147838

Kant, R., Kant, R., \& Jaiswal, D. (2017). The impact of perceived service quality dimensions on customer satisfaction: An empirical study on public sector banks in India. International Journal of Bank Marketing, 35(3), 411-430. https://doi.org/10.1108/IJBM-04-2016-0051

Kwan, W., \& Hee, T. J. (1994). Measuring service quality in Singapore retail banking: A gap analysis \& segmentation approach. Singapore Management Review, 16(2), 1. http://connection.ebscohost.com/c/articles/6915289/measuring-service-quality-singapore-retail-banking-gap -analysis-segmentation-approach

Lassar, W. M., Manolis, C., \& Winsor, R. D. (2000). Service quality perspectives and satisfaction in private banking. Journal of Services Marketing, 14(2/3), 244-271. https://doi.org/10.1108/08876040010327248

Lee, H., Lee, Y., \& Yoo, D. (2000). The determinants of perceived service quality and its relationship with satisfaction. The Journal of Services Marketing, 14(3), 217-231. https://doi.org/10.1108/08876040010327220

Loqman \& Muhiuddin. (1998). Performance evaluation in terms of profitability and productivity of interest-free banking system - a case study on Islamic Bank Bangladesh Ltd. Chittagong University Studies.

Malhotra, N. K., Agarwal, J., \& Peterson, M. (1996). Methodological issues in cross-cultural marketing research: A state-of-the-art review. International Marketing Review, 13(5), 7-43. https://doi.org/10.1108/02651339610131379

Michel, S. (2004). Consequences of perceived acceptability of a bank's service failures. Journal of Financial Services Marketing, 8(4), 367-377. https://doi.org/10.1057/palgrave.fsm.4770133

Mohadevan \& Balasubramanian. (2001). Need for commitment to quality and customer service quality in Indian banking sector. Indian Journal of Marjketing, 13-19.

Naser, K., \& Moutinho, L. (1997). Strategic marketing management: The case of Islamic banks. International Journal of Bank Marketing, 15(6), 187-203. https://doi.org/10.1108/02652329710184424

Palmer, A., \& Cole, C. (1995). Services marketing: Principles and practice. NJ: Prentice-Hall, Englewood, Cliffs.

Parasuraman, A., Berry, L. L., \& Zeithaml, V. A. (1991). Refinement and reassessment of the servqual scale. Journal of Retailing, 67(4), 420. http://psycnet.apa.org/record/1992-37673-001

Parasuraman, A., Zeithaml, V. A., \& Berry, L. L. (1985). A conceptual model of service quality and its implications for future research. Journal of Marketing, 49(4). https://doi.org/10.2307/1251430

Rahman, S. M. H. (2001). Islamic banking revisited. Thoughts on Economics, 11(3-4). http://archive.thedailystar.net/forum/2010/april/islamic.htm

Saleh, M. A., Quazi, A., Keating, B., \& Gaur, S. S. (2017). Quality and image of banking services: A comparative study of conventional and Islamic banks. International Journal of Bank Marketing, 35(6), 878-902. https://doi.org/10.1108/IJBM-08-2016-0111

Shemwell, D. J., \& Yavas, U. (1999). Bringing banks out of darkness: Eliminating remnants of the cultural malaise of yesteryear. Journal of Financial Service Marketing, 4, 334-343.

Siddiqui, M. N. (1985). Partnership and profit sharing in Islamic law. Leicester: The Islamic Foundation.

Sivapalan, A., \& Jebarajakirthy, C. (2017). An application of retailing service quality practices influencing customer loyalty toward retailers. Marketing Intelligence \& Planning, 35(7), 2017. https://doi.org/10.1108/MIP-09-2016-0178

Spreng, R. A., \& Mackoy, R. D. (1996). An empirical examination of a model of perceived service quality and 
satisfaction. Journal of Retailing, 72(2), 201-214. https://doi.org/10.1016/S0022-4359(96)90014-7

Strauss, A., \& Corbin, J. (1990), Basics of qualitative research: Grounded theory, procedures and techniques. London: Sage Publications.

Taylor, S. A., \& Baker, T. L. (1994). An assessment of the relationship between service quality and customer satisfaction in the formation of consumers' purchase intentions. Journal of Retailing, 70(2), 163-178. https://doi.org/10.1016/0022-4359(94)90013-2

Teas, R. K. (1993). Expectations, performance evaluation, and consumers' perceptions of quality. Journal of Marketing, 57(4), 18-34. https://doi.org/10.2307/1252216

Yavas, U., \& Yasin, M. M. (2001). Enhancing organizational performance in banks: A systematic approach. The Journal of Services Marketing, 15(6/7), 444-453. https://doi.org/10.1108/EUM0000000006099

\section{Copyrights}

Copyright for this article is retained by the author(s), with first publication rights granted to the journal.

This is an open-access article distributed under the terms and conditions of the Creative Commons Attribution license (http://creativecommons.org/licenses/by/4.0/). 